WOOD AND STEM ANATOMY OF BERGIA SUFFRUTICOSA:

RELATIONSHIPS OF ELATINACEAE AND BROADER SIGNIFICANCE OF VASCULAR TRACHEIDS,

VASICENTRIC TRACHEIDS, AND FIBRIFORM VESSEL ELEMENTS

SHERWIN CARLQUist

Made in United States of America

Reprinted from ANNALS OF THE Missouri Botanical Garden

Vol. 71, No. 1, 1984

(C) Missouri Botanical Garden 1984 


\title{
WOOD AND STEM ANATOMY OF BERGIA SUFFRUTICOSA: RELATIONSHIPS OF ELATINACEAE AND BROADER SIGNIFICANCE OF VASCULAR TRACHEIDS, VASICENTRIC TRACHEIDS, AND FIBRIFORM VESSEL ELEMENTS
}

\author{
SHERWIN CARLQUisT ${ }^{1}$
}

\begin{abstract}
Bergia suffruticosa Fenzl provided sufficient lower stem and upper stem material to compare wood and stem anatomy to those of putatively related families: Clusiaceae (including Hypericaceae), Frankeniaceae, Lythraceae, and Haloragaceae. Of these, only Clusiaceae proves close; resemblances to Bergia include presence of simple perforation plates, presence of tracheids as the imperforate tracheary element type, presence of vasicentric tracheids and fibriform vessel elements, predominance of uniseriate rays with some biseriates, vertical orientation of scalariform vessel-ray pitting, absence of intraxylary phloem, abundance of brownish compounds in parenchyma cells, and occurrence of druses and solitary crystals. Other features such as seed anatomy confirm the relationship of Elatinaceae and Clusiaceae. The presence and nature of vasicentric tracheids in Bergia suffruticosa and Clusiaceae prompts an examination of this cell type. Vascular tracheids are defined here as: (1) present in latewood only (except for some genera in which all wood is like latewood); (2) not always present near vessels; (3) characteristic mostly of drought-deciduous shrubs; (4) about the same length as vessel elements in any wood in which they occur; (5) with pits like those of the vessel elements; and (6) present in families so specialized that the imperforate tracheary element type is the libriform fiber (rarely the fibertracheid). Vasicentric tracheids, in contrast, are (1) distributed in earlywood as well as in latewood and can occur in diffuse porous; (2) always occur near vessels; (3) are wider, somewhat shorter, and more densely pitted than associated imperforate tracheary elements although they always bear pits like those of vessels; (4) may be associated with fiber-tracheids (with various types of pitting) or libriform fibers, depending on the species; and (5) occur in trees or shrubs that may be evergreen or winter-deciduous, but tend to be unlike the shrubs (predominantly from families in which herbaceous species are frequent or preponderant) in which vascular tracheids occur. Vascular tracheids as defined here do not have vestigial perforations; cells with such perforations are regarded as vessel elements by definition. Fibriform vessel elements (perforate but intermediate in size and shape between tracheids and wide vessel elements) have been reported in other groups, notably vines, where fibriform vessel elements may result from vessel dimorphism (lateral enlargement of narrow vessels preempted by the great widening of a few vessels). Fibriform vessel elements may also occur in some nonvining families, such as Hydrophyllaceae, however.
\end{abstract}

Although some data are available on stem anatomy (mostly primary stem) of Bergia suffruticosa (Metcalfe \& Chalk, 1950), the nature of secondary xylem has not been described for this species, the only species of Elatinaceae that could be considered at all woody. The material kindly provided me by Dr. Peter H. Raven included stems and some small roots. Roots were not large enough to make study of root wood feasible. No material of leaves or flowers was provided, and those structures are therefore not included in the present study.

Although wood anatomy is often not decisive in delineating relationships of dicotyledon families, wood anatomy of Bergia suffruticosa proves unusually valuable in indicating the probable relationships of Elatinaceae. The affinities of Elatinaceae have been claimed by various authors to include such families as Clusiaceae (including Hypericaceae), Frankeniaceae (and the allied family Tamaricaceae), Lythraceae, and Haloragaceae (C. D. Cook in Heywood, 1978). These four groups are located in four disparate orders, respectively-Theales, Tamaricales (near Cistales), Myrtales, and Cornales-according to the system of Thorne (1976). Opinions are not equally divided on which of these groups is most closely related to Elatinaceae. A few authors have favored placement near Frankeniaceae and Tamaricaceae (e.g., Wettstein, 1935). Hutchinson

\footnotetext{
' Rancho Santa Ana Botanic Garden and Department of Biology, Pomona College, Claremont, California
} 91711. 
(1959) claimed affinity of Elatinaceae with Caryophyllaceae. However, more recent phylogenists opt unanimously for placement of Elatinaceae in Theales near Clusiaceae (Cronquist, 1981; Dahlgren, 1980; Takhtajan, 1980; Thorne, 1976). The families Clusiaceae and Hypericaceae are very close and are treated as a single family by most authors, such as the four just cited. I will follow that treatment in my discussion, and I will use the name Clusiaceae for the combined family.

The wood of Bergia suffruticosa demonstrates an unusual near-continuum in morphology between wide vessel elements, fibriform vessel elements, and tracheids. This phenomenon proves referable to concepts variously designated by particular terms. The concepts of vascular tracheids, vasicentric tracheids, fibriform vessel elements, and vessel dimorphism are compared and contrasted. The functional nature of these phenomena is also explored. Further work to refine definitions of these cell types is needed.

\section{Materials AND MethodS}

Of the liquid-preserved specimens of Bergia suffruticosa placed at my disposal, one series, vouchered by the specimen $B$. C. Daramo 6 (MO), was selected because xylem accumulation was maximal and straight stem portions suitable for sectioning were present. This material was collected from a shrub $90 \mathrm{~cm}$ tall growing near the Numan Bridge on the Benu River near Numan, Gongola, Nigeria. The liquid-preserved material was provided as bottles labeled "stems" and "roots" respectively. However, sections of the latter revealed presence of pith and endarch xylem. Therefore these segments have been designated "lower stems," and those labeled as stems have been designated as "upper stems" in the descriptions that follow. Bergia suffruticosa is branched from near the base; the "lower stem" is below most of this branching whereas the upper stems, much smaller in diameter, are taken from above most of this branching.

The lower stems of Bergia suffruticosa have wide vessels (Fig. 1). Upper stems are small in diameter, and have a thin but tough cylinder of secondary xylem (Fig. 10). These features would lead to fragmentation of vessel walls and of sections with ordinary rotary microtome or sliding microtome techniques. Such small stems are, moreover, difficult to handle with a sliding microtome. Therefore a new method in which infiltration and embedding in paraffin are preceded by treatment of the material in ethylene diamine (Carlquist, 1982) was used. The softening action of the ethylene diamine was hastened by placing the material being treated in a paraffin oven $\left(60^{\circ} \mathrm{C}\right)$ for four hours. Sections were stained with a safranin-fast green combination.

Macerations were prepared from pickled material with Jeffrey's Fluid. Macerations were stained with safranin.

For comparison with Bergia suffruticosa, wood of several species of Clusiaceae was sectioned. These wood samples are part of the Rancho Santa Ana Botanic Garden wood sample collection, but are designated by serial numbers of the U.S. National Museum, which contributed them to that collection. This material did not require special softening techniques and was sectioned on a sliding microtome and stained with safranin. Macerations were prepared with Jeffrey's Fluid and stained with safranin.

\section{Anatomical Descriptions}

Lower stem (Figs. 1-9). Growth rings absent; larger vessel elements tend to be progressively wider in diameter (Fig. 1). Vessel elements range up to $230 \mu \mathrm{m}$ in diameter. Perforation plates are simple. Cells that appear to be imperforate tracheary elements as seen in transection include both fibriform vessel elements (Fig. 3) and tracheids. Fibriform vessel elements are more numerous than the tracheids but grade into them, as well as into the wider vessel elements. Because there is a complete intergradation among classes of tracheary elements, none of these classes can be isolated for the purposes of measurement, and only extremes can be quantified. Wider vessel elements are about $320 \mu \mathrm{m}$ long, tracheids are about $600 \mu \mathrm{m}$ long. Wall thickness of wider vessels is $7 \mu \mathrm{m}$, wall thickness of tracheids, $3 \mu \mathrm{m}$. Intervascular pitting of vessels is composed of alternate pits that can be polygonal in outline where crowded (Fig. 7), otherwise circular in outline or somewhat laterally widened (Fig. 6); pits average about $6 \mu \mathrm{m}$ in diameter. Vessel-ray pitting is composed of circular or elongate pits, the latter often elongate parallel to the long axis of the stem (Fig. 6), a kind of scalariform pattern. Vessel-ray pitting is bordered on the vessel side, simple on the ray cell side. Axial parenchyma is in strands of two cells. Axial parenchyma is often beside larger vessels (Fig. 4), but can also be scattered among other tracheary elements (Fig. 5). Because the fibriform vessel elements are so 
abundant, virtually all axial parenchyma may be adjacent to vessel elements and is therefore paratracheal. Rays are uniseriate to multiseriate (Fig. 2 ), wide multiseriate rays are infrequent. Rays mostly have lignified walls, a few have thin nonlignified walls (Fig. 2). Ray cells are mostly erect or square; a few procumbent cells are present, but these are only a little longer radially than tall axially. Some ray cells are idioblastic and bear tanninlike compounds (Figs. 2, 4). Secretory canals are absent from rays. Wood is nonstoried. Druse-bearing cells and tannin-bearing cells occur idioblastically in both cortex and pith (Figs. $8,9)$. Starch grains are frequent in parenchyma cells in both cortex and pith. Protophloem fibers are present (Fig. 8) and tend to be scattered in groups rather than as a continuous cylinder around the stem.

Upper stem (Figs. 10-12). Widest vessels about $70 \mu \mathrm{m}$ in diameter (Fig. 10). Perforation plates simple. Vessels are quadrangular in transectional outline near pith, as claimed by Metcalfe and Chalk (1950), but rounded in outline otherwise, suggesting that very little secondary xylem was present in the material studied by Metcalfe and Chalk. Length of wider vessel elements is about $400 \mu \mathrm{m}$; length of tracheids is about $530 \mu \mathrm{m}$. Fibriform vessel elements are present, somewhat less abundant in comparison to wider vessel elements and tracheids than they are in the lower stem. Pits on vessel elements are alternate, about $5 \mu \mathrm{m}$ in diameter. Fully bordered pits are present on tracheids (Fig. 12). Axial parenchyma is sparse. Rays are mostly uniseriate (Fig. 11), but some biseriate rays are present. Very few rays are more than two cells wide (a maximum of four cells wide was seen). Ray cells are erect only, no square or procumbent cells were seen. Secretory canals are absent in rays. Wood is nonstoried. Druses are present in pith and cortex; solitary crystals are present as chambered crystals in strands of phloem parenchyma. Tanninlike compounds are present in idioblastic cells in both cortex and pith, also in xylem parenchyma. Protophloem fibers are present, forming a nearly complete cylinder inside the cortex.

\section{RELATIONSHips of ElatinaceaE}

One can consider Clusiaceae, TamaricaceaeFrankeniaceae, Lythraceae, and Haloragaceae as comprising the four groups to which Elatinaceae is compared in the present paper. All of these families except Clusiaceae have libriform fibers with simple pits, in contrast to Elatinaceae, in which tracheids bearing fully bordered pits are present (Fig. 12). While this discrepancy does not absolutely rule out a relationship, most families of dicotyledons do not have a wide range of pitting in imperforate tracheary elements.

Myrtalean affinity of Elatinaceae seems ruled out additionally because Elatinaceae lacks intraxylary phloem and vestured pits, features present in Lythraceae (Baas \& Zweypfenning, 1979).

An undetermined Australian species of Frankenia represented in my wood slide collection has rayless wood, a feature not present in Bergia suffruticosa. Tamarix has unusually wide rays (10-25 cells wide), but has few or no uniseriate rays according to Metcalfe and Chalk (1950). Tamaricaceae has storied wood. Thus Frankeniaceae and Tamaricaceae contrast with Elatinaceae.

Although wood of Haloragaceae does not differ sharply from that of Elatinaceae except in having simple pits in imperforate tracheary elements, other differences in stem anatomy may be found. For example, Haloragaceae have crystals in trichomelike cells in the cortex; such cells are absent in Elatinaceae. The distribution of protophloem fibers in Haloragaceae (where such fibers are rare) is unlike that of Elatinaceae.

Affinity of Elatinaceae with Clusiaceae, the relationship claimed for Elatinaceae by recent phylogenists, can be supported by numerous wood features, in contrast with the above comparisons. Imperforate tracheary elements with fully bordered pits (Figs. 15, right; 16, right; 19, right) exactly like those on vessel elements (and thus tracheids) occur in both families. The occurrence of a tracheary element type intermediate in morphology between tracheids and wide vessel elements, termed fibriform vessel elements above, can be seen in Hypericum (Fig. 19, left) as well as in Bergia suffruticosa (Fig. 3). The occurrence of vasicentric tracheids in Calophyllum and other Clusiaceae is an allied phenomenon discussed below. Rays in Clusiaceae are most often uniseriate or biseriate (Figs. 14,15), although somewhat wider rays have definitely been reported. The presence of a few wide rays in the lower stem of Bergia suffruticosa (as compared to the upper stem) may be an interpolation related to starch and water storage, and probably does not represent any remnant of any hypothetical widerrayed condition. The predominant erectness of 

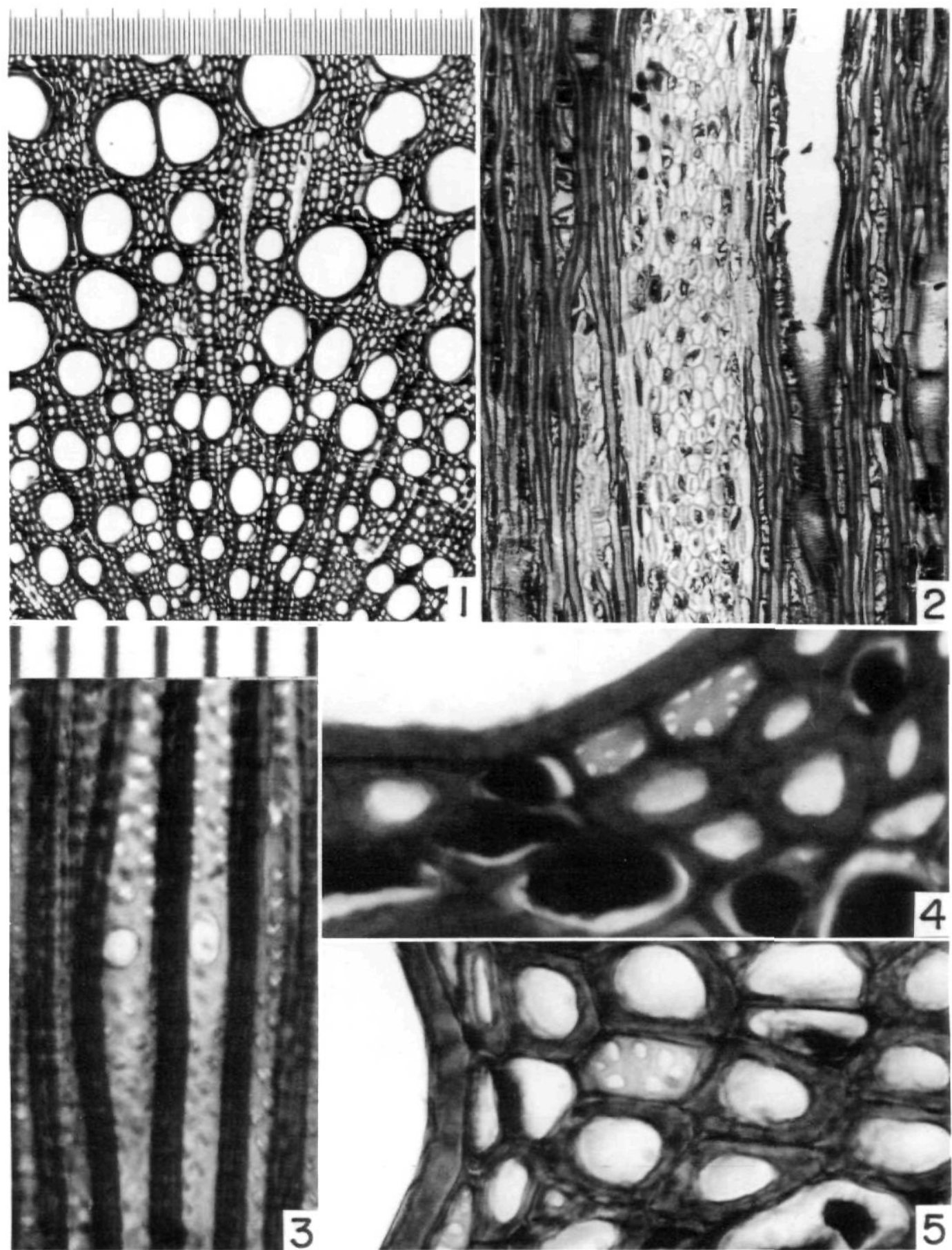

Figures 1-5. Sections of lower stem of Bergia suffruticosa, Daramo 6 (MO). - 1. Transection; note wide vessels. -2 . Tangential section. Wide multiseriate ray, center; other rays are mostly uniseriate or biseriate. -3 . Portion of radial section, showing two tracheids (left) and three fibriform vessel elements with small perforation plates (right). -4 . Transection; ray cells filled with tanninlike deposit. -5 . Transection. Axial parenchyma cells near center and adjacent to vessel, lower left. Figures 1, 2, magnification scale above Figure 1 (finest divisions = $10 \mu \mathrm{m}$ ). Figures $3-5$, magnification scale above Figure 3 (divisions $=10 \mu \mathrm{m}$ ). 

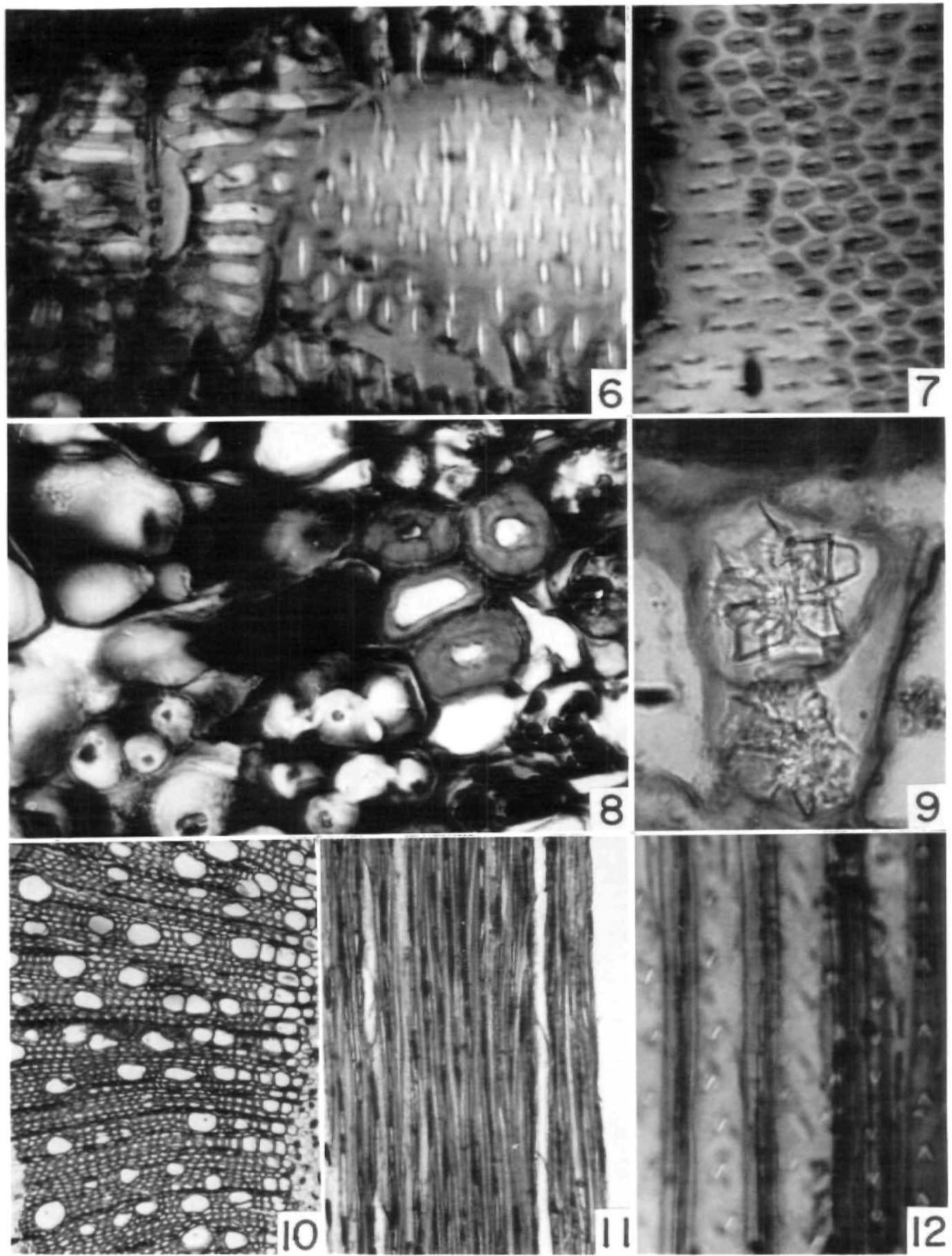

Figures 6-12. Sections of Bergia suffruticosa, Daramo 6 (MO). 6-9. Sections of lower stem. -6. Portions of vessel from radial section (long axis of vessel oriented left to right). Note vertically elongate vessel-ray pitting, left. -7 . Vessel wall from radial section; pits are alternate, polygonal to rounded in outline. -8 . Portion of stem transection, cortical cells with tannin and starch, left; protophloem fibers, right. -9 . Druse from cortex of stem transection. 10-12. Sections of upper stem. -10 . Transection of secondary xylem, pith margin at right. -11 . Tangential section, rays very narrow. -12 . Portions of tracheids from radial section; pits fully bordered. Figures $6-9,12$, magnification scale above Figure 3. Figures 10, 11, magnification scale above Figure 1. 
ray cells in Bergia suffruticosa is doubtless related to its stature as an herb, judging from characteristics of herbs and herblike plants discussed earlier (Carlquist, 1962). Diffuse parenchyma, as in Elatinaceae, can be found in a few Clusiaceae, such as Mammea (Metcalfe \& Chalk, 1950), but a wide range in parenchyma types exists in Clusiaceae, ranging from apotracheal bands, as in Calophyllum (Figs. 13, 18) to absent, as in $\mathrm{Hy}$ pericum (Fig. 20), or paratracheal (as can be claimed for Bergia) in Tovomitopsis (Metcalfe \& Chalk, 1950). Vessel-ray pitting in Bergia suffruticosa may be scalariform, the pits elongate vertically (Fig. 6); this can be found in Clusiaceae also (Fig. 17). Presence of brown-colored compounds, presumptively regarded as tanninlike above, is widespread in dicotyledons, but these are very abundant in Bergia suffruticosa and in Clusiaceae. Secretory canals are absent in rays of Bergia, but they are absent in many Clusiaceae also. Druses and solitary crystals are widespread in dicotyledons; both types occur both in Elatinaceae and in Clusiaceae, however. The major reasons for allying Elatinaceae with Clusiaceae lie in gross morphology, the more important wood features outlined above, and in seed anatomy (Corner, 1976). Because of parallel aneuploidy in Clusiaceae and in Elatinaceae, chromosome number similarities may be inconclusive (Raven, 1975).

\section{VASCUlar Tracheids, Vasicentric TraChEIDS, FIBRIFORM VESSELS, AND VESSEL DimorphisM: DEFINITIONS AND SigNIFICANCE}

Among the anatomical features for which listings of families are given by Metcalfe and Chalk $(1950,1983)$ is presence of vasicentric tracheids. This feature, however, seems not to have received extensive comment in any paper. Vasicentric tracheids may be closely allied to other types of tracheary elements. Consequently, definitions and discussion are offered here. This discussion may be regarded as preliminary, and refinements and modifications are to be expected.

Vascular tracheids. Vascular tracheids are vessel elements so narrow that they lack perforation plates. Criteria for their recognition include the following. (1) They occur in woods that have sharply demarcated growth rings, and the vascular tracheids always occur in latewood only. Exceptions to this may be found in woods that represent such a high degree of xeromorphy that all wood in those species is comparable to latewood, as in Loricaria thuyoides (Carlquist, 1961) or globular cereoid cacti (Gibson, 1973). (2) Vascular tracheids are known only in highly specialized wood in which imperforate tracheary elements have simple pits only and therefore are libriform fibers. A minor exception is formed by Calycanthaceae, in which fiber-tracheids (with quite vestigial borders, however) are present and in which vascular tracheids easily distinguishable from the fiber-tracheids occur (Carlquist, 1983). (3) Vascular tracheids tend to be the same length as the vessel elements in any given sample, but are appreciably shorter than the libriform fibers with which they are associated. When comparing vascular tracheids to vasicentric tracheids (below), distribution within the wood is the most important of the above criteria. Thus, although Calycanthaceae are listed by Metcalfe and Chalk $(1950,1983)$ as having vasicentric tracheids, the family actually has vascular tracheids, formed only in the latewood of growth rings. The drawing of a transection of Chimonanthus fragrans wood by Metcalfe and Chalk does not include any indication of vasicentric tracheids (which are denoted by a special pattern in drawings of the woods that do have vasicentric tracheids elsewhere in their book). Vascular tracheids are found in such families as Asteraceae (Carlquist, 1960), Cactaceae (Gibson, 1973), and Scrophulariaceae (Michener, 1981). Functionally, vascular tracheids offer the safety of true tracheids under drought conditions in that air embolisms cannot spread from one vascular tracheid into another, whereas air bubbles can spread from one vessel element into numerous vessel elements subadjacent or superadjacent. Tracheary elements like vascular tracheids but with vestigial or pitlike perforations are not admitted as vascular tracheids here, but are considered vessel elements if any perforation occurs. Vascular tracheids probably occur most commonly in drought-deciduous shrubs; their occurrence is not familiar to those who study wood of trees exclusively.

Vasicentric tracheids. Judging from systematic occurrence (Metcalfe \& Chalk, 1950: 1351; 1983: 205), vasicentric tracheids must have arisen more than once in dicotyledons, and therefore may not represent a uniform phenomenon. However, the following criteria may be used to identify and define vasicentric tracheids. (1) Vasicentric tracheids are imperforate cells that bear fully bordered pits like the pits of vessel elements in the woods in which they occur. (2) Vasicentric 

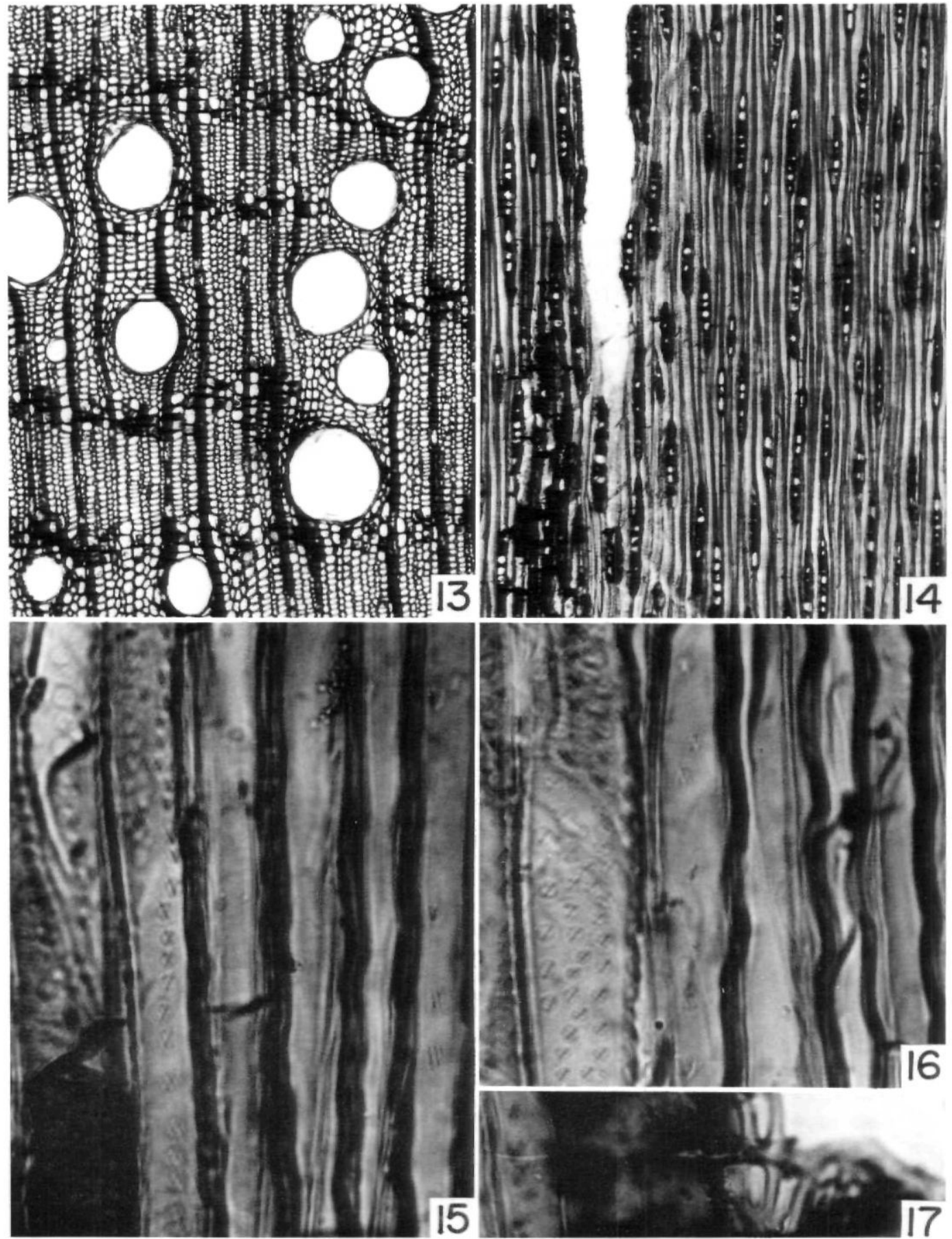

Figures 13-17. Calophyllum vitiense, USw-16369, wood sections. - 13. Transectional vessels are solitary apotracheal banded parenchyma visible because of dark-staining contents. -14 . Tangential section. Rays uniseriate, biseriate, rich in dark-staining contents. $-15,16$. Portions of radial section; in each, vasicentric tracheids at left, fiber-tracheids at right, showing character of these two cell types and their bordered pits. -17 . Portion of radial section; vessel-ray pitting at center, pits vertically elongate forming a scalariform pattern. Figures 13 , 14, magnification scale above Figure 1. Figures 15-17, magnification scale above Figure 3. 

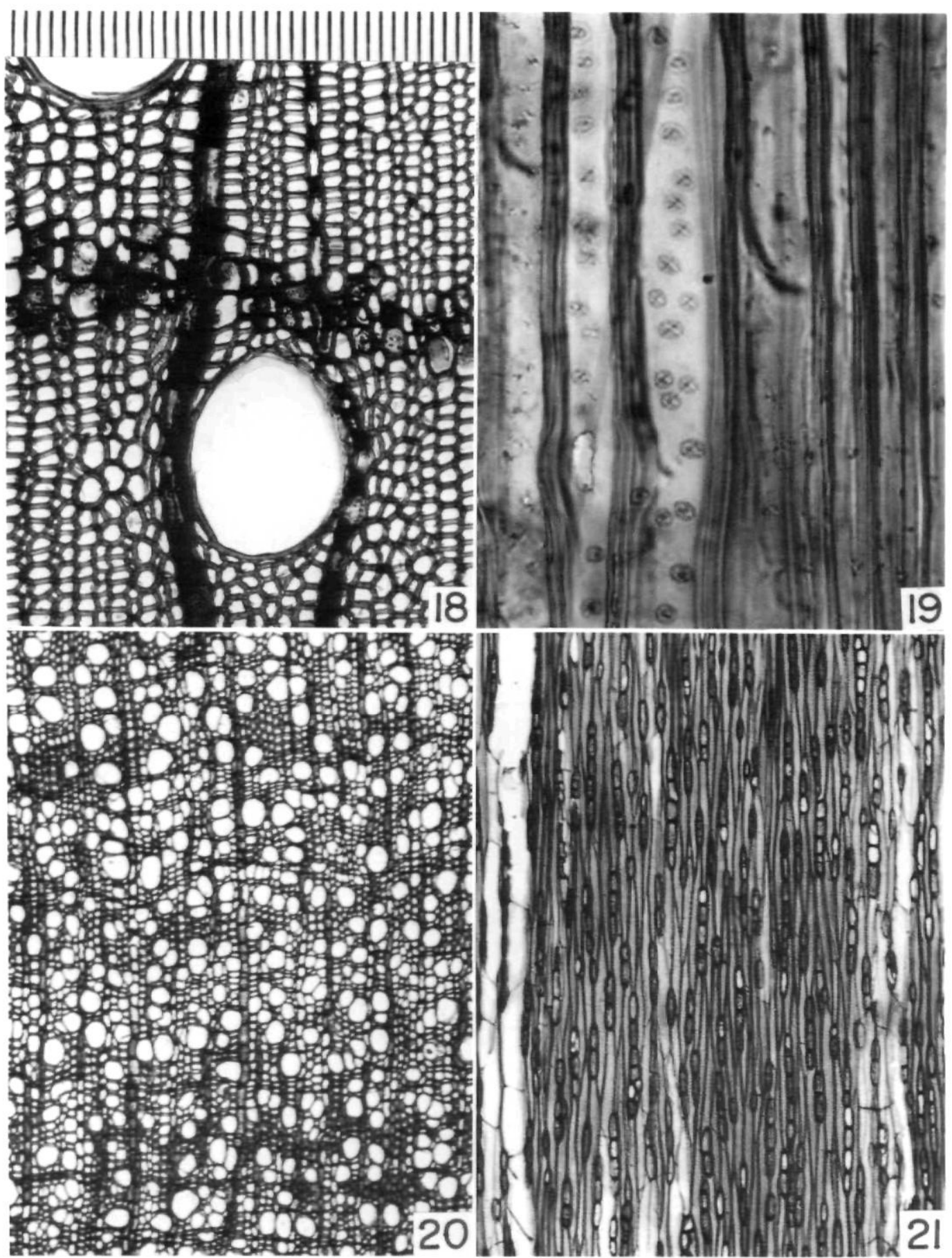

FIGURES 18-21. Wood sections of Clusiaceae.-18. Calophyllum vitiense, USw-16369, transection; vasicentric tracheids are visible as cells larger in diameter than ordinary tracheids, to left of lower vessel and below upper vessel. 19-21. Hypericum galioides, USw-14006, wood sections. - 19. Radial section; perforation plate visible in fibriform vessel, left; other cells at right are vasicentric tracheids. -20 . Transection; vessels very narrow, numerous. -21 . Tangential section; rays are mostly uniseriate. Figure 18, magnification scale above Figure 18 (divisions $=10 \mu \mathrm{m}$ ). Figure 19, magnification scale above Figure 3. Figures 20, 21, magnification scale above Figure 1. 
tracheids are distributed around vessels and vessel groups. (3) Vasicentric tracheids tend to be at least somewhat longer than vessel elements in any given wood. (4) Vasicentric tracheids are not distributed with relation to growth rings and are present in earlywood as well as in latewood. Vasicentric tracheids may occur in woods without growth rings (e.g., Calophyllum, Fig. 13). The diffuse porous woods in which they occur are not so highly xeromorphic that the entirety of the wood may be regarded as a kind of latewood, a phenomenon true of the wood of cacti, cited above, in which vascular tracheids occur. (5) Vasicentric tracheids tend to be wider than the remaining imperforate tracheary elements in woods in which they occur (Figs. 15, left; 16, left; 18). (6) Vasicentric tracheids tend to be more densely pitted than the remaining imperforate tracheary elements in woods in which they occur (Figs. 15, left; 16, left; 19).

Vasicentric tracheids may grade from cells very similar to the imperforate tracheary elements in the woods in which they occur to very unlike the imperforate tracheary elements they accompany. If a wood has true tracheids, vasicentric tracheids would be indistinguishable from true tracheids, and by definition we can say that vasicentric tracheids are absent in woods with true tracheids. Calophyllum (Figs. 13-18) has what may be termed fiber-tracheids that are more slender, longer, and more sparsely pitted than the vasicentric tracheids in that wood. This situation may also be found in Asclepias albicans Watson. On the other hand, Connarus has vasicentric tracheids markedly different from the libriform fibers which form the ground tissue of wood in that genus (Dickison, 1972). I have observed association of vasicentric tracheids with libriform fibers in Oceanopapaver neocaledonicum Guillaumin, a member of Capparaceae.

Hypericum galioides (Figs. 19-21) has fibertracheids with bordered pits in addition to vasicentric tracheids. However, there are also elongate vessel elements that resemble tracheids but that have small perforation plates (Fig. 19). These may be termed fibriform vessel elements because they are narrow, long, and with pointed ends as compared with ordinary vessel elements. Presence of fibriform vessel elements is characteristic of Bergia suffruticosa, but in that species all imperforate tracheary elements must be termed tracheids, and therefore no vasicentric tracheids can be said to occur.

The functional significance of vasicentric tra- cheids seems potentially much like that of vascular tracheids. Vasicentric tracheids form an excellent subsidiary conductive system in case of occlusion of vessels by air embolisms, theoretically. Indeed, in many of the species with vasicentric tracheids, vessels are notably large and therefore vulnerable (Calophyllum, Connarus. Quercus). Other species with vasicentric tracheids occur in notably dry habitats (Asclepias albicans, Oceanopapaver neocaledonicum) so that a subsidiary conducting system composed of tracheids and thus safer than a system composed only of vessel elements plus presumptively nonconductive libriform fibers would have a positive selective value. However, vasicentric tracheids would be of high value, theoretically, precisely because of their distribution in wood: they surround vessels so that if the vessels are disabled, the three-dimensional conduction patterns are minimally rerouted. The potential significance of maintaining this network intact can be realized if one notes that libriform fibers (which presumably function little if at all in conduction) or ray cells frequently separate one vessel from another in a particular wood, so that a three-dimensional rerouting across such relatively nonconductive cells is not possible. This would seem an advantage of vasicentric tracheids over vascular tracheids until one takes into account that vascular tracheids are formed in large numbers and are often in association with very narrow vessels, which are relatively safer than wider vessels, so that rerouting of conduction in case of embolisms in narrow vessels is also likely to be minimal. Vascular tracheids and vasicentric tracheids may be successful for many of the same reasons, but probably occur in different kinds of plants.

Fibriform vessel elements. This term was originated by Woodworth (1935) to describe slender vessel elements, fusiform in shape and often longer than the ordinary vessel elements they accompany in any given wood in which they occur. Because the tips of these cells are pointed, the perforations are subterminal and often appear lateral thereby. Some fibriform vessel elements can be considered under the heading of vessel dimorphism below. Others, however, appear to have nothing to do with any kind of vessel dimorphism. In Eriodictyon (Carlquist et al., 1983) and other Hydrophyllaceae (Carlquist \& Eckhart, 1984), fibriform vessel elements are present but vessel dimorphism cannot be said to 
occur: vessel elements intermediate in diameter are frequent. In the Hydrophyllaceae in which fibriform vessel elements occur, there is a continuum not merely in diameter of vessel elements, but between fibriform vessel elements and tracheids (or fiber-tracheids) in the genera $\mathrm{Er}$ iodictyon, Turricula, and Wigandia. There may be an adaptive value for production of the narrow fibriform vessel elements, for narrow vessels ought to be adaptive in plants of dry areas such as those occupied by Eriodictyon (Carlquist, 1966, 1975).

Vessel dimorphism. The term vessel dimorphism was used earlier (Carlquist, 1981) to denote the tendency in a vining family (Nepenthaceae) for vessels to be either very wide or else very narrow and fibriform with a small perforation plate (often only a little larger than a bordered pit). The latter class of vessel elements was, in that family, only slightly longer than the former. This tendency can be found in other vining families of dicotyledons, such as Convolvulaceae, in which Mennega (1969) termed the slender vessel elements "fibres" with "apertures" (= perforations) on their radial walls. These elements also have bordered pits and thus do not differ from the wide vessel elements except in their shape and size.

Probably the phenomenon of vessel dimorphism applies to virtually all vining families and genera. It can be regarded as a byproduct of the production of very wide vessels, which are adaptive in vining plants for reasons suggested elsewhere (Carlquist, 1975). In this hypothesis, the production of few but very wide vessels would preempt the widening of many vessel elements, which thereby are destined to become fibriform vessel elements. A slightly greater length for fibriform vessel elements as compared with the wide vessel elements they accompany in a particular wood may be expected simply because slender cells tend to retain greater intrusive capacities than wide ones. Fibriform vessel elements in a species with vessel dimorphism would theoretically form an effective part of the conductive system, albeit small in capacity when compared to the very great hydraulic capacities of the wide vessel elements.

Obviously the characteristics of vessel elements, vascular tracheids, and vasicentric tracheids may vary somewhat from any particular scheme, and thus generalizations are premature. Consequently, the listing of vasicentric tracheids given by Metcalfe and Chalk $(1950,1983)$ should be regarded as a starting-point for research, not as a summation.

\section{Literature Cited}

BAAS, P. \& R. C. V. J. ZWEYPFENNING. 1979. Wood anatomy of the Lythraceae. Acta Bot. Neerl. 28: 117-155.

Carlquist, S. 1960. Wood anatomy of Astereae (Compositae). Trop. Woods 113: 54-84.

- 1961. Wood anatomy of Inuleae (Compositae). Aliso 5: 21-37.

- 1962. A theory of paedomorphosis in dicotyledonous woods. Phytomorphology 12: 30-45.

_. 1966. Wood anatomy of Compositae: a summary, with comments on factors controlling wood evolution. Aliso 6(2): 25-44.

- 1975. Ecological Strategies of Xylem Evolution. Univ. of California Press, Berkeley and London.

- 1981. Wood anatomy of Nepenthaceae. Bull. Torrey Bot. Club 108: 324-330.

. 1982. The use of ethylenediamine in softening hard plant structures for paraffin sectioning. Stain Technol. 57: 311-317.

- 1983. Wood anatomy of Calycanthaceae: ecological and systematic implications. Aliso 10: 427-441.

- \& V. M. ECKHART. 1984. Wood anatomy of Hydrophyllaceae. II. Genera other than Eriodictyon, with comments on parenchyma bands containing vessels with large pits. Aliso 10: (in press). $\longrightarrow$ \& D. C. Michener. 1983. Wood anatomy of Hydrophyllaceae. I. Eriodictyon. Aliso 10: 397-412.

Corner, E. J. H. 1976. The Seeds of Dicotyledons. Cambridge Univ. Press, Cambridge.

Cronquist, A. 1981. An Integrated System of Classification of Flowering Plants. Columbia Univ. Press, New York.

DAHLGREN, R. 1980. A revised system of classification of the angiosperms. J. Linn. Soc., Bot. 80: 91124.

Dickison, W. C. 1972. Anatomical studies in the Connaraceae. II. Wood anatomy. J. Elisha Mitchell Sci. Soc. 88: 120-136.

Gibson, A. C. 1973. Comparative anatomy of secondary xylem in Cactoideae (Cactaceae). Biotropica 5: 29-65.

Heywood, V. H. 1978. Flowering Plants of the World. Mayflower Books, New York.

Hutchinson, J. 1959. The Families of Flowering Plants. Volume 1. Dicotyledons. Oxford Univ. Press, Oxford.

MennegA, A. M. W. 1969. The wood structure of Dicranostyles (Convolvulaceae). Acta Bot. Neerl. 18: 173-179.

Metcalfe, C. R. \& L. Chalk. 1950. Anatomy of the Dicotyledons. Clarendon Press, Oxford.

- \& -1983 . Anatomy of the Dicotyledons. Edition 2. Volume II. Wood Structure and Conclusion of the General Introduction. Clarendon Press, Oxford.

MiChenER, D. C. 1981. Wood and leaf anatomy of 
Keckiella (Scrophulariaceae): ecological considerations. Aliso 10: 39-57.

RAVEN, P. H. 1975. The bases of angiosperm phylogeny: cytology. Ann. Missouri Bot. Gard. 62: 724-764.

TAKHTAJAN, A. L. 1980. Outline of the classification of flowering plants (Magnoliophyta). Bot. Rev. (Lancaster) 46: 225-359.
THORNE, R. F. 1976. A phylogenetic classification of the Angiospermae. Evol. Biol. 9: 35-106.

WettStein, R. 1935. Handbuch der Systematischen Botanik. Franz Deuticke, Leipzig and Wien.

WOODWORTH, R. H. 1935. Fibriform vessel members in the Passifloraceae. Trop. Woods 41: 8-16. 